\title{
Persistence and occurrence of SARS-CoV-2 in water and wastewater environments: a review of the current literature
}

\author{
Ananda Tiwari ${ }^{1} \cdot$ Nati Phan ${ }^{2} \cdot$ Sarmila Tandukar ${ }^{3} \cdot$ Razieh Ashoori $^{4} \cdot$ Ocean Thakali ${ }^{5} \cdot$ Milad Mousazadesh $^{6,7}$. \\ Mohammad Hadi Dehghani ${ }^{8,9} \cdot$ Samendra P. Sherchan ${ }^{2}$
}

Received: 29 July 2021 / Accepted: 1 October 2021 / Published online: 15 October 2021

(c) The Author(s), under exclusive licence to Springer-Verlag GmbH Germany, part of Springer Nature 2021

\begin{abstract}
As the world continues to cope with the COVID-19 pandemic, emerging evidence indicates that respiratory transmission may not the only pathway in which the virus can be spread. This review paper aims to summarize current knowledge surrounding possible fecal-oral transmission of SARS-CoV-2. It covers recent evidence of proliferation of SARS-CoV-2 in the gastrointestinal tract, as well as presence and persistence of SARS-CoV-2 in water, and suggested future directions. Research indicates that SARS-CoV-2 can actively replicate in the human gastrointestinal system and can subsequently be shed via feces. Several countries have reported SARS-CoV-2 RNA fractions in wastewater systems, and various factors such as temperature and presence of solids have been shown to affect the survival of the virus in water. The detection of RNA does not guarantee infectivity, as current methods such as RT-qPCR are not yet able to distinguish between infectious and non-infectious particles. More research is needed to determine survival time and potential infectivity, as well as to develop more accurate methods for detection and surveillance.
\end{abstract}

Keywords Coronavirus · COVID-19 · Fecal-oral transmission · Waterborne transmission · Wastewater · Disinfection . Persistence

\section{Introduction}

\section{Background on the COVID-19 pandemic}

In December of 2019, the severe acute respiratory syndrome coronavirus 2 (SARS-CoV-2) was discovered in

Responsible Editor: Lotfi Aleya

Samendra P. Sherchan

sshercha@tulane.edu

1 Expert Microbiology Unit, Finnish Institute for Health and Welfare, P.O. Box 95, 70701 Kuopio, Finland

2 Department of Environmental Health Sciences, Tulane University, 1440 Canal Street, New Orleans, LA 70112, USA

3 Policy Research Institute, Sano Gaucharan, Kathmandu, Nepal

4 Department of Environmental Health Engineering, School of Health, Shiraz University of Medical Sciences, Shiraz, Iran

5 University of Yamanashi, Takeda, Kofu, Yamanashi 4-3-11 400-8511, Japan
Wuhan, China (Harapan et al. 2020). Multiple cases of pneumonia with an unknown cause had been reported early in the month, and by January 7, SARS-CoV-2 was identified in a patient's throat swab sample (Harapan et al. 2020). This virus has led to the COVID-19 pandemic, which is the third, and largest, coronavirus outbreak since the severe acute respiratory syndrome coronavirus (SARS-CoV-1) outbreak from 2002 to 2003 and the Middle East respiratory

6 Qazvin University of Medical Sciences, Qazvin, Iran

7 Department of Environmental Health Engineering, School of Health, Qazvin University of Medical Sciences, Qazvin, Iran

8 Department of Environmental Health Engineering, School of Public Health, Tehran University of Medical Sciences, Tehran, Iran

9 Center for Solid Waste Research, Institute for Environmental Research, Tehran University of Medical Sciences, Tehran, Iran 
syndrome (MERS-CoV) outbreak of 2012 (Wathore et al. 2020). According to the World Health Organization (WHO), as of May 2021, there have been over 3,311,780 confirmed deaths due to this disease (WHO 2021). The pandemic has had a large impact on people's freedom, liberty, and quality of life, as it brings many challenges as a threat to human health as well as the global economy (Rahmani and Mirmahaleh 2021).

\section{Coronaviridae family}

The novel human coronavirus was first discovered in the mid-1960s, with seven types reported today (Buonerba et al. 2021). The SARS-CoV-2 belongs to Betacoronavirus (betaCoV) genus of the subfamily Orthocoronavirinae of the Coronaviridae family, of the order Nidovirales (Harapan et al. 2020; Cascella et al. 2021). Coronavirinae is divided into four genera, Alphacoronavirus, Gammacoronavirus, Deltacoronavirus, and Betacoronavirus, which contains the highly pathogenic viruses SARS-CoV, MERS-CoV, and SARS-CoV-2 (Harapan et al. 2020). The Coronaviridae family is a group of "enveloped, single-stranded positive-sense RNA viruses" (p.1) that mainly infect birds and mammals, including humans (Hartenian et al. 2020). Coronaviruses generally have four types of structural proteins, including spike, envelope, membrane, and nucleocapsid (Figure 1) (Tarighi et al. 2021). The term corona originates from the viral membrane's spike glycoprotein that forms the peplomers on the surface of the virus, which creates a crown-like structure (Ortiz-Prado et al. 2020). These spike membrane proteins help facilitate viral entry as they bind and fuse with the membrane of the host cell (Hartenian et al. 2020). After entry, it is cleaved into two functional subunits by the host protease, which then facilitates host cell binding and viral-cellular membrane fusion (Tarighi et al. 2021). Tarighi et al. (2021) note that the recognition of proteases and entry receptors will vary based on the type of coronavirus. Because of their similarities in structure, previous studies on SARS-CoV-1, MERS-CoV, and other enveloped viruses can provide some reference for SARS-CoV-2 to a certain extent (Van Doremalen et al. 2020).

SARS-CoV and MERS-CoV (betaCoVs of the B and C lineage, respectively) are considered to be more virulent and capable of causing epidemics manifesting with respiratory and extra-respiratory manifestations of variable clinical severity (Cascella et al. 2021). Currently, seven human CoVs (HCoVs) capable of infecting humans have been identified. In general, estimates suggest that $\sim 2 \%$ of the population are a healthy carrier of CoVs and that these viruses are responsible for about $5-10 \%$ of acute respiratory infections (Cascella et al. 2021).

\section{SARS-CoV-2}

It is presumed that the original zoonotic transmission of SARS-CoV-2 occurred through a natural genetic mutation that allowed the virus to infect humans (Buonerba et al. 2021). The genomic characterization of SARS-CoV-2 is $89 \%$ nucleotide identity with bat SARS-like-CoVZXC21 and $82 \%$ with that of human SARS-CoV (Cascella et al. 2021). The SARS-CoV-2 sequence is $96 \%$ homologs with known animal coronaviruses betaCoV RaTG13 of bats (Rhinolophus affinis). The SARS-CoV-2 is an enveloped virus, meaning that it is encased in a lipid cell membrane from the host cell that protects the bits of proteins and genetic material within (Tran et al. 2021). The virus is a spherical shape and

Fig. 1 Cell structure of SARS$\mathrm{CoV}-2$

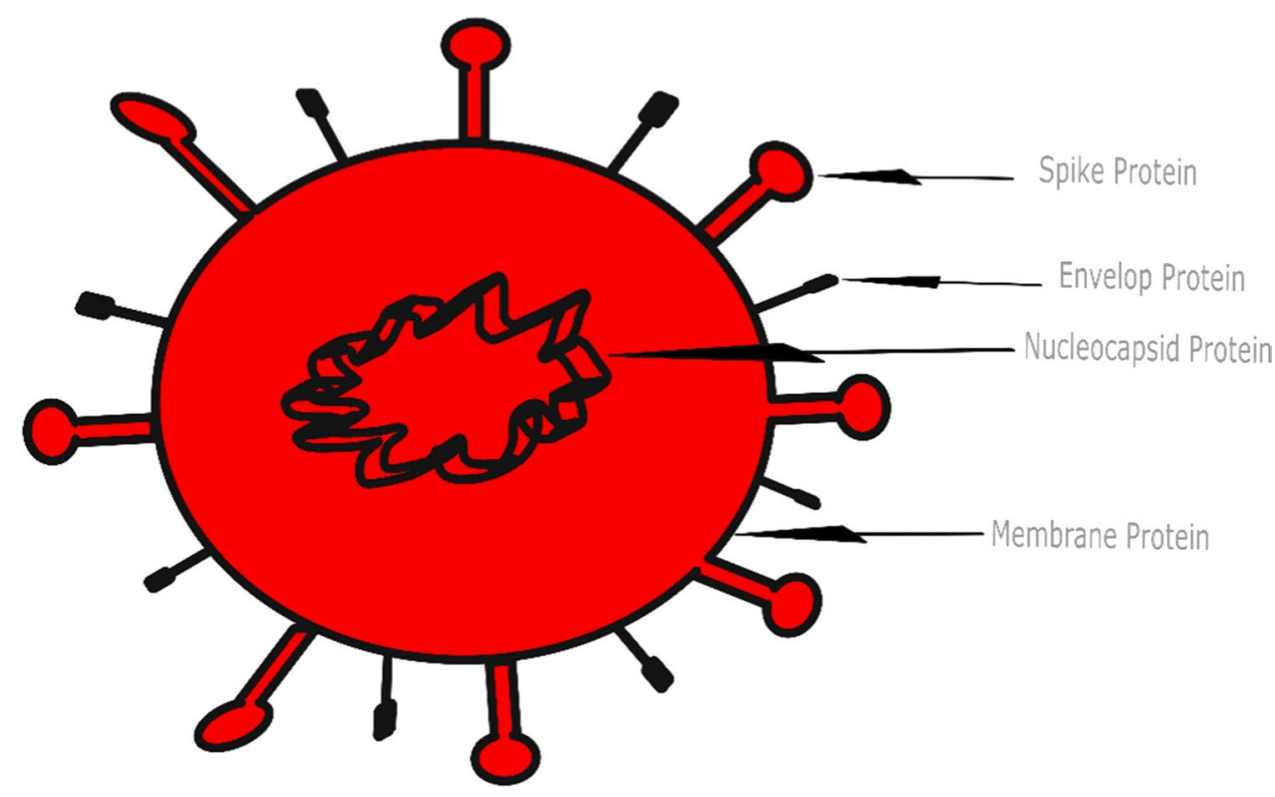


roughly $120 \mathrm{~nm}$ in diameter, with a helical capsid within the envelope containing the RNA genome and nucleoprotein ( $\mathrm{La}$ Rosa et al. 2020). SARS-CoV-2 has single-stranded RNA with 29891 nucleotides, encoding for 9860 amino acids (Cascella et al. 2021). However, SARS-CoV-2 is different from other coronaviruses in that it has a unique rigid shell that promotes persistence and stability outside the human body (Goh et al. 2020).

This virus targets the upper-lower respiratory system, which may result in lung infection or other respiratory complications (Rahmani \& Mirmahaleh, 2021). The incubation period for COVID-19 can be anywhere between 2 and 14 days, during which the virus enters respiratory cells, specifically type 2 pneumonocytes and ciliated bronchial epithelial cells (Yazdanpanah et al. 2021). This occurs through "attachment between angiotensin-converting enzyme 2 (ACE2) receptors and spike glycoprotein (S glycoprotein)" (Yazdanpanah et al. 2021, p.1). Symptoms of the SARSCoV-2 infection include "fever, dry cough, dyspnea, chest pain, fatigue, and myalgia (Wölfel et al. 2020). Less common symptoms include headache, dizziness, abdominal pain, diarrhea, nausea, and vomiting" (Harapan et al. 2020, p. 670). In severe cases, SARS-CoV-2 can cause pneumonia, kidney failure, or even death (Wathore et al. 2020). However, many cases are asymptomatic, which creates a challenging public health problem (Al-Tawfiq 2020).

\section{SARS-CoV-2 transmission and risk factors}

It is now known that SARS-CoV-2 is spread from person-toperson through aerosols/droplets containing infectious virus from infected individuals (symptomatic, asymptomatic, pre-symptomatic, and pseudo-symptomatic), created from breathing, coughing, or sneezing (La Rosa et al. 2020). The expelled droplets are thought to only be of concern within a 2-m distance (Ortiz-Prado et al. 2020). During human-tohuman transmission, an average of 1000 infectious SARS$\mathrm{CoV}-2$ virions are thought to initiate a new infection (Popa et al. 2020). The disease may also be spread through direct contact with an infected person or indirect contact with a contaminated surface and subsequent transfer of the virus to the mouth, nose, or eyes (La Rosa et al. 2020). The US CDC recently released a technical report and mentioned individuals can be infected with SARS-CoV-2 via contact with surfaces contaminated by the virus, but the risk is low and is not the main route of transmission of this virus (https://www. cdc.gov/coronavirus/2019-ncov/more/science-and-resea rch/surface-transmission.html). Additionally, Ortiz-Prado et al. 2020) state $50 \%$ of transmissions "occur secondary to exposure to an asymptomatic people" (p.1). The virus has been shown to survive up to 14 days on surfaces under the right conditions and still remain infective, with smooth surfaces such as plastic and wood being more favorable for virus survival (Chin et al. 2020). An individual infected with SARS-CoV-2 sheds the RNA of the virus for roughly 14 to 21 days, with approximately $10^{2}$ to $10^{8}$ RNA copies per gram (Gwenzi 2021).

Risk factors for contracting SARS-CoV-2 include chronic comorbidities such as cardiovascular disease, cerebrovascular disease, or diabetes, as well as old age (Harapan et al. 2020). Other factors that have been linked to higher risk of mortality from COVID-19 include being male, hypertension, obesity, and chronic obstructive pulmonary disease (Gazzaz, 2021).

\section{SARS-CoV-2 prevention, diagnosis, and treatment}

Social distancing and enforced quarantine have proved as effective methods for reducing the spread of the disease, especially in cities that are prone to quick spread of the virus (Rahmani and Mirmahaleh 2021). Other methods used to slow the spread of the virus include hand hygiene and personal protective equipment (PPE) (Gwenzi 2021). However, these methods for preventing the spread of the disease are based on the premise that the virus is spread through respiratory droplets (Gwenzi 2021).

There are multiple procedures recommended for diagnosing patients with suspected COVID-19 infection. Samples from sputum, nasopharyngeal swab, lower respiratory tract secretions, blood, or fecal/anal swabs may be used with realtime polymerase chain reaction to detect positive nucleic acid of SARS-CoV-2 (Yazdanpanah et al. 2021). Despite the large spread of the pandemic, there is currently no specific medication against COVID-19 (Tarighi et al. 2021). However, as of December 2020, several mRNA vaccines against COVID-19 have been approved for use (Hall et al. 2021). Vaccines have proven effective in reducing SARS-CoV-2 infections in both symptomatic and asymptomatic individuals and have shown evidence of reducing transmission as well (Hall et al. 2021).

\section{Emerging waterborne transmission concern}

Though the main transmission route has been noted as inhaling infected droplets or aerosols, other potential methods of transmission such as the fecal-oral route have been suggested (Buonerba et al. 2021). This recent concern is due to found presence of SARS-CoV-2 in fecal samples and anal swabs of some patients (La Rosa et al. 2020). Additionally, traces of SARS-CoV-2 have been found in untreated wastewater, medical wastewater, secondary-treated wastewater, river water, municipal sewage, wastewater treatment plant-derived sludges, and wastewater from cruise ships and aircrafts (Tran et al. 2021). Furthermore, evidence suggests that many enveloped viruses can remain infective in aqueous environments for 
days to months (Paleologos et al. 2020). This has generated concern for the possibility of fecal-oral transmission of SARS-CoV-2, especially as flushing allows the virus to enter sewage systems and can aerosolize fecal matter, which can also lead to airborne transmission (Wathore et al. 2020). This could be of particular concern for fecal-oral transmission of COVID-19 in developing countries due to risk factors such as poor water sanitation (Gwenzi 2021).

Considering this emerging concern, this paper will investigate the behavior of SARS-CoV-2 in water and the possibility of fecal-oral or waterborne transmission. The review will discuss current knowledge of SARS-CoV-2 in the gastrointestinal tract, presence of SARS-CoV-2 in water, and persistence of SARS-CoV-2 in water. It will then cover the significance of this possible transmission pathway, methodology for detection, and recommended future directions.

\section{Methods}

This literature review was conducted in April of 2021 using several different electronic databases. The online scholarly databases used in this search included (1) PubMed, (2) ScienceDirect, (3) NCBI, (4) PMC, (5) MDPI, and (6) Google Scholar, among others.

Articles were collected with no restriction for language; however, if articles were written in a language other than English, the English version of the article was read for this review. Date restriction for this review includes articles no older than 5 years before 2021. Considering the ever-evolving pool of knowledge surrounding the current pandemic, articles that were published more recently were reviewed first.

Boolean search techniques were employed for this literature review to search for a combination of keywords using "AND," "OR," and "NEAR." Keywords and their variants, including "COVID-19," "SARS-CoV-2," "coronavirus," "waterborne transmission," "fecal-oral transmission," "fecaloral route," "drinking water," and "water persistence," were used among others. Furthermore, given the limited research on waterborne and fecal-oral transmission SARS-CoV-2 specifically, the search was also extended to SARS-CoV-1 and MERS-CoV.

The articles retrieved in the literature review were manually screened for relevance to this study's aim. Additional articles were gathered by searching reference lists in other collected relevant articles, as well as viewing suggested similar articles linked to each article provided by the database. Each article was analyzed, and relevant information was extracted to be summarized in this paper.

\section{Literature review}

\section{SARS-CoV-2 in the gastrointestinal tract}

Up until the SARS-CoV-1 outbreak in 2002, coronaviruses were thought to only be respiratory pathogens; however, it was discovered that SARS-CoV-1 could affect the human enteric tract (Buonerba et al. 2021). Furthermore, in the MERS outbreak of 2012, MERS-CoV RNA was also detected in the stool of infected patients (Yeo et al. 2020). Viruses spread from infected cells to non-infected cells, meaning viral transmission routes are determined by viral-specific target cells or organs (Xiao et al. 2020a, b). Following viral entry, RNA and proteins specific to the virus will assemble new virions in the cytoplasm, which may then be released into the gastrointestinal tract (Xiao et al. 2020a, b). Emerging evidence has indicated SARS-CoV-2 proliferates in the gastrointestinal system, and fecal samples of coronavirus patients can remain positive for the SARS-CoV-2 RNA even after respiratory tract samples became negative (Wu et al. 2020). Evidence has shown that fecal shedding of the virus can occur before symptoms arise during the incubation period, during illness, and after recovery (Gwenzi 2021). Between late January and early February of 2020, Xiao et al. (2020a, b) collected fecal samples from 28 COVID-19 patients to find 12 were positive for viral RNA. Additionally, researchers successfully isolated the SARS-CoV-2 virus from two of the patients with positive viral RNA, which indicates that the presence of the infectious virus in feces is common in the manifestation of COVID-19 (Xiao et al. 2020a, b). Another study conducted in January and February of 2020 focused on three pediatric cases of COVID-19 and found viral RNA to remain positive for over 4 weeks, compared to a 2-week clearance in the respiratory tract following the end of fever symptoms (Xing et al. 2020). Yeo et al. (2020) reported infectious SARS-CoV-2 from fecal samples and suspected the possibility of fecal-oral transmission.

Using RNA detection and intracellular staining, Xiao et al. (2020a, b) found that SARS-CoV-2 was able to infect gastrointestinal glandular epithelial cells, and their evidence suggests that infectious virions are secreted from these infected cells. This suggests that the virus is able to actively replicate in the gastrointestinal tract and provides plausible evidence for fecal-oral transmission even after clearance in the respiratory system (Wu et al. 2020). This has prompted aqueous media, particularly wastewater, to be treated as a potential transmission carrier as it can be contaminated with coronaviruses through feces (Buonerba et al. 2021). 


\section{SARS-CoV-2 in water bodies}

As water can be a medium for pathogens to spread and cause disease outbreaks, fecal contamination of water supplies has long been recognized as human health risk (La Rosa et al. 2020). In particular, enteric (non-enveloped) viruses have been the center of concern for waterborne transmission as they are excreted through the feces of an infected individual (La Rosa et al. 2020). As enveloped viruses such as SARSCoV-2 are structurally dissimilar to enteric viruses, they have been assumed to behave differently in water (La Rosa et al. 2020). However, the role of waterborne viral infections has been underestimated with coronaviruses in the past (Buonerba et al. 2021). In particular, this was the case in the 2003 SARS epidemic in Hong Kong, as bioaerosols were generated via aeration in sewer pipes and subsequently spread SARS-CoV-1 in a private housing estate (Buonerba et al. 2021). It should be noted that due to their similarities in structure and research implicating similarities in stability in aerosols and on surfaces, previous evidence from studies on SARS-CoV-1, MERS-CoV, and other coronaviruses can provide references for SARS-CoV-2 (Van Doremalen et al. 2020). Researchers at the time analyzed sewage discharges from two hospitals accommodating SARS patients in Beijing, China (La Rosa et al. 2020). Although viral genome was repeatedly detected, there was no presence of infectious SARS-CoV-1 found, though this was hypothesized to be due to the large amounts of disinfectants used in the hospital when patients had bowel movements (La Rosa et al. 2020).

Gwenzi (2021) reviewed several water-based epidemiological studies to find wastewater and on-site sanitation systems that serve as reservoirs for SARS-CoV-2 from both point and non-point sources. Sources found were "(1) feces released via the toilet system, (2) household wastewaters from bathing of infected persons, (3) laundry wastewater from washing of infectious materials such as contaminated clothes and personal protective equipment, and (4) wastewaters from health care, autopsy and thanatopraxy/embalming facilities, including funeral homes" (Gwenzi 2021, p.5). Furthermore, Gwenzi (2021) states that there is a growing body of literature reporting SARS-CoV-2 RNA in raw wastewater.

Brief examples of studies conducted on SARS-CoV-2 in wastewater are shown in Table 1 . An early study in Australia conducted sampling in March and April of 2020, to find SARS-CoV-2 in wastewater using reverse transcriptase quantitative polymerase chain reaction (RT-qPCR) (Ahmed et al. 2020). Ultrafiltration and direct extraction of RNA from electronegative membranes were used to concentrate virus samples (Ahmed et al. 2020). Ahmed et al. (2020) found concentrations of SARS-CoV-2 RNA to range from $1.9 \times 10^{1}$ to $1.2 \times 10^{2}$ copies/L. This proof of concept study was the first to document the detection of SARS-CoV-2
RNA in untreated wastewater in Australia (Ahmed et al. 2020).

Another early study conducted in Louisiana by Sherchan et al. (2020) was the first to detect SARS-CoV-2 RNA in wastewater in North America. Samples of both treated and untreated wastewater were collected between January and April of 2020 (Sherchan et al. 2020). Two methods were used to concentrate wastewater samples, including ultrafiltration and absorption-elution, along with RT-qPCR to find SARS-CoV-2 RNA in two out of 15 samples (Sherchan et al. 2020). Concentrations of SARS-CoV-2 RNA ranged from $3.1 \times 10^{3}$ to $7.5 \times 10^{3}$ copies/L, however not detected in secondary-treated or final effluent samples (Sherchan et al. 2020).

A similar study conducted in Spain between March and April 2020 used an aluminum hydroxide adsorption-precipitation method to concentrate samples and RT-qPCR to detect viral RNA (Randazzo et al. 2020). Out of 42 influent and 18 secondary and 12 tertiary-treated effluent samples, $83 \%$ of influent and $11 \%$ of effluent samples tested positive for a minimum of one SARS-CoV-2 RT-qPCR target (Randazzo et al. 2020)

Another study conducted in the Netherlands also tested sewage samples in February and March of 2020 with four RT-qPCR assays (Medema et al. 2020). Researchers found positive detections in three sites and found a slight positive correlation between increasing RNA signal detection and increase of COVID-19 prevalence (Medema et al. 2020). Concentrations began at a low of 2.6-30 gene copies per $\mathrm{mL}$ in February and rose to a high of 790-2200 gene copies per $\mathrm{mL}$ in March (Medema et al. 2020).

A study conducted in China analyzed septic tanks of the Wuchang Cabin Hospital, a temporary hospital open between February 5 and March 10 created for COVID-19 patients (Zhang et al. 2020). Septic tanks at the hospital contained wastewater from both toilets and showers in the hospital and were disinfected with sodium hypochlorite before being discharged to wastewater treatment plants (Zhang et al. 2020). Sewage first went through a preliminary disinfection tank before entering the septic tank (Zhang et al. 2020). Both influent and effluent samples were collected from the septic tanks and tested with RT-qPCR. Results showed a high level of gene copies $\left(0.5 \times 10^{3}\right.$ copies $/ \mathrm{L}$ to $18.7 \times 10^{3}$ copies $\left./ \mathrm{L}\right)$ even after disinfection with sodium hypochlorite (Zhang et al. 2020). When a larger amount of sodium hypochlorite was used, effluent samples were negative; however, there were high levels of disinfection by-product residuals which could have many ecological risks (Zhang et al. 2020).

SARS-CoV-2 RNA has also been detected in household wastewaters including in toilets, washbasin siphons, and shower siphons (Döhla et al. 2020). Döhla et al. (2020) sampled 66 wastewater samples from 21 households to find $15.15 \%$ (10 out of 66) of wastewater samples to test positive 
Table 1 Summary of studies conducted on SARS-CoV-2 detection in water bodies samples (the viral load is indicated in terms of genomic units per unit of volume $(\mathrm{GU} / \mathrm{L}$ or $\mathrm{GU} / \mathrm{mL})>$ )

\begin{tabular}{|c|c|c|c|c|}
\hline Location, date of sampling & Plants and type of sampling & Details on the study & SARS-CoV-2 load & Ref \\
\hline $\begin{array}{l}\text { South East Queensland, } \\
\text { Australia. } 27 \text { Mar and } 1 \\
\text { Apr } 2020\end{array}$ & $\begin{array}{l}\text { - } 2 \text { WWTPs and a pumping } \\
\text { station } \\
\text { - Automated samplers or } \\
\text { grab sampling }\end{array}$ & $\begin{array}{l}\text { - } 22.2 \%(2 / 9) \text { of samples } \\
\text { tested positive }\end{array}$ & $\begin{array}{l}\text { Range: } \\
1.9 \times 10^{1}-1.2 \times 10^{2} \mathrm{GU} / \mathrm{L}\end{array}$ & Ahmed et al. (2020) \\
\hline $\begin{array}{l}\text { Southern Louisiana, USA. } \\
\text { From Jan to Apr } 2020\end{array}$ & $\begin{array}{l}\text { - } 2 \text { WWTPs } \\
\text { - 24-h composite and grab } \\
\text { samples collected monthly }\end{array}$ & - 2/7 samples tested positive & $\begin{array}{l}\text { N1 assay: } \\
7.5 \times 10^{3} \mathrm{GU} / \mathrm{L} \\
\mathrm{N} 2 \text { assay: } \\
3.1 \times 10^{3}-4.3 \times 10^{3} \mathrm{GU} / \mathrm{L}\end{array}$ & Sherchan et al. (2020) \\
\hline $\begin{array}{l}\text { Region of Murcia, Spain. } \\
\text { From } 12 \text { Mar to } 14 \text { Apr } \\
2020\end{array}$ & $\begin{array}{l}\text { - } 6 \text { WWTPs serving the } \\
\text { major municipalities }\end{array}$ & $\begin{array}{l}\text { - } 83 \%(35 / 42) \text { of samples } \\
\text { were positive for at least } \\
\text { one target }\end{array}$ & $\begin{array}{l}\text { Average values: } \\
\text { N1: } 5.1 \pm 0.3 \log _{10} \mathrm{GU} / \mathrm{L} \\
\mathrm{N} 2: 5.5 \pm 0.2 \log _{10} \mathrm{GU} / \mathrm{L} \\
\mathrm{N} 3: 5.5 \pm 0.3 \log _{10} \mathrm{GU} / \mathrm{L}\end{array}$ & Randazzo et al. (2020) \\
\hline $\begin{array}{l}\text { The Netherlands. From } 5 \\
\text { Feb to } 16 \text { Mar } 2020\end{array}$ & $\begin{array}{l}\text { - 24-h flow-dependent } \\
\text { composite samples }\end{array}$ & $\begin{array}{l}\text { - } 58 \%(14 / 24) \text { of samples } \\
\text { were positive } \\
\text { - On } 4 / 5 \text { March ( } 1 \text { week } \\
\text { into the epidemic), } 4 / 6 \\
\text { WWTPs were positive, } \\
\text { with only } 38 \text { and } 82 \\
\text { COVID-19 cases con- } \\
\text { firmed through the health } \\
\text { surveillance system }\end{array}$ & $\begin{array}{l}\text { Range: } \\
2.6 \times 10^{3}-2.2 \times 10^{6} \mathrm{GU} / \mathrm{L}\end{array}$ & Medema, et al. (2020) \\
\hline $\begin{array}{l}\text { Wuhan, China, From } 5 \text { Feb- } \\
\text { ruary and } 10 \text { March }\end{array}$ & - Wuchang Cabin Hospital & & $\begin{array}{l}\text { Range: } \\
0.5 \times 10^{3}-18.7 \times 10^{3} \log _{10} \\
\quad \text { GU/L }\end{array}$ & Zhang et al. (2020) \\
\hline Germany. March 2020 & $\begin{array}{l}\text { - } 66 \text { wastewater samples } \\
\text { from } 21 \text { households }\end{array}$ & $\begin{array}{c}\text { - } 15.15 \% \text { (10 out of } 66) \text { of } \\
\text { samples tested positive }\end{array}$ & n.a & Döhla et al. (2020) \\
\hline $\begin{array}{l}\text { Virginia, USA. From } 9 \text { Mar } \\
\text { to } 28 \text { Jul } 2020\end{array}$ & $\begin{array}{l}\text { - } 9 \text { WWTPs } \\
\text { - } 24 \text {-h flow weighted } \\
\text { composite samples taken } \\
\text { weekly in } 3 \text { WWTPs } \\
\text { - Grab sampling in the } \\
\text { other } 3 \text { WWTPs }\end{array}$ & $\begin{array}{l}\text { - } 198 \text { samples were ana- } \\
\text { lyzed: } \\
98 \text { positive for } 3 \text { assays, } \\
22 \text { positive for } 2 \text { assays, } \\
\text { and } 30 \text { positive for only } \\
1 \text { assay } \\
\text { - COVID-19-confirmed } \\
\text { cases were } 69 \text { on } 9 \text { March, } \\
\text { and they increased to } \\
1,180,000 \text { on } 28 \text { July }\end{array}$ & $\begin{array}{l}\text { Range: } \\
10^{2}-10^{5} \mathrm{GU} / \mathrm{L}\end{array}$ & Gonzalez et al. (2020) \\
\hline $\begin{array}{l}\text { North-Rhine Westphalia, } \\
\text { Germany. } 8 \text { Apr } 2020\end{array}$ & $\begin{array}{l}\text { - } 9 \text { WWTPs } \\
\text { - } 24 \text {-h flow-dependent } \\
\text { composite samples } \\
\text { - Sampling during dry } \\
\text { weather }\end{array}$ & & $\begin{array}{l}\text { Range: } \\
\text { 3-20 GU/mL }\end{array}$ & Westhaus et al. (2021) \\
\hline
\end{tabular}

for SARS-CoV-2 RNA through RT-qPCR. Following these results, researchers suggested, "mouthwash in washbasins, body wash in the shower and feces in toilets and therefore wastewater could pose a relevant exposure" (Döhla et al. 2020, p.12). Furthermore, other research has also suggested possible transmission of SARS-CoV-2 via recreational and rehabilitation pools, as well as public baths (Cahill and Morris 2020; Romano-Bertrand et al. 2020).

According to Buonerba et al. (2021), "the detection of the virus in wastewater is not directly correlated to the infectivity" (p.2). Buonerba et al. (2021) also state that despite high SARS-CoV-2 RNA concentrations found worldwide in wastewaters, recent research has "have indicated a scarce persistence of the virus in these water media" (p.2). RNA fragments or molecules can still be detected from viral particles that are damaged or inactive; however, there is no current established method for estimating infectious particles (Tiwari et al. 2021; Buonerba et al. 2021; Gwenzi 2021). This creates a challenge in attempting to infer the potential human health risks based on SARS-CoV-2 RNA detection in environmental media (Gwenzi 2021). Up until now, available research has not provided much information on persistence of SARS-CoV-2 in aquatic environments (Patel et al. 2021). The following section will provide evidence found in this review concerning SARS-CoV-2 persistence in water. 


\section{Persistence in water bodies}

Viral persistence is essential for its transmission; however, this depends on a variety of factors (Patel et al. 2021). In particular, initial viral load, medium type, temperature, organic matter, and presence of biological fluid, organic, or inorganic substances can influence SARS-CoV-2 survival and sustainability (Patel et al. 2021). Understanding persistence of microorganisms in water allows for more accurate definition of the level of hazards for humans (Buonerba et al. 2021). Evidence has shown that coronaviruses are able to persist up to a few weeks in aqueous media, although many other factors affect their viability and infectivity (Buonerba et al. 2021). Considering the limited time since the beginning of the pandemic, research concerning the persistence of SARS-CoV-2 in wastewater has been restricted (Race et al. 2020). Therefore, observations of surrogates such as other coronavirus or the murine hepatitis virus have been used to preliminarily describe the persistence of SARS-CoV-2 in water (Bivins et al. 2020). Additionally, some recent studies have performed SARS-CoV-2 cultivation experiments to analyze persistence of the virus (Bivins et al. 2020).

Carducci et al. (2020) discuss several previous studies focused on SARS-CoV-1. One study found infectivity to be undetectable in room temperature water after 3 to 4 days, and another saw a reduction in infective SARS-CoV-1 after 2 days in $20^{\circ} \mathrm{C}$ water; however at $4{ }^{\circ} \mathrm{C}$, the reduction was not seen until 14 days (Carducci et al. 2020). Through their review of multiple studies, they indicate that human coronaviruses and their surrogates are less resistant in water when compared to non-enveloped viruses (Carducci et al. 2020). Additionally, survival is reduced in organically and microbially polluted waters and increased temperatures increase viral inactivation (Carducci et al. 2020).

Results of a review by La Rosa et al. (2020) also concurs that coronavirus survival decreases with increasing temperature and that coronaviruses are inactivated faster than non-enveloped human enteric viruses. Results also indicate coronaviruses are sensitive to oxidants such as chlorine, and no current evidence has shown presence of human coronaviruses in surface or groundwater, or ability to be transmitted through contaminated drinking water (La Rosa et al. 2020). However, more research is needed to explore coronavirus persistence in water under various climatic and seasonal conditions (La Rosa et al. 2020).

Another meta-analysis similarly found coronaviruses and other surrogates to have an increase in persistence with a decrease in temperature (Silverman and Boehm 2020). Mean decay rate constants were also found to increase in temperature in the absence of disinfectants (Silverman and Boehm 2020). At room temperature, defined as between 22 and $25{ }^{\circ} \mathrm{C}$, mean decay rate constants ranged from 2.9 \pm 0.03 per day in sterilized wastewater (Silverman and
Boehm 2020). Furthermore, Silverman and Boehm (2020) suggest that increases in decay rate constants could be due to various factors such as enzyme activity, predation, and presence of solvents, detergents, or organic matter in wastewater; however, there has been no specific evidence to confirm this.

Race et al. (2020) discusses studies that showed time for 99.9\% of coronavirus titer to decrease was higher in unfiltered wastewater when compared to filtered wastewater at the same temperature. This indicates higher solid content in water or wastewater could be protective for the virus, which could be attributed to the hydrophobic nature of the coronavirus envelope as this leads to lower viral solubility which may promote adhesion of the virus to solid particles (Race et al. 2020).

One recent study by Bivins et al. (2020) inoculated untreated primary influent water from a municipal wastewater treatment plant with SARS-CoV-2 in order to analyze persistence of infectivity and RNA signal. This study was conducted over 7 days with starting titers of $10^{5}$ and $10^{3}$ tissue culture infectious dose per milliliter $\left(\mathrm{TCID}_{50} \mathrm{~mL}^{-1}\right)$; it is noted that these viral concentrations are over the expected concentrations in sewage as high amounts are needed to determine inactivation kinetics (Bivins et al. 2020). Wastewater and tap water were analyzed at $20^{\circ} \mathrm{C}$, while wastewater was also analyzed at 50 and $70{ }^{\circ} \mathrm{C}$ to test the potential effectiveness of heat treatment (Bivins et al. 2020). Infectious SARS-CoV-2 was detected for 7 days at the $10^{5} \mathrm{TCID}_{50}$ $\mathrm{mL}^{-1}$ level and 3 days at the $10^{3} \mathrm{TCID}_{50} \mathrm{~mL}^{-1}$ level (Bivins et al. 2020). Researchers found "times for $90 \%$ reduction of viable SARS-CoV-2 in wastewater and tap water at room temperature were 1.5 and 1.7 days, respectively" (p.937). Additionally, in wastewater at 50 and $70{ }^{\circ} \mathrm{C}$, the times for $90 \%$ reduction values for infectious SARS-CoV-2 dropped to 15 and $2 \mathrm{~min}$, respectively (Bivins et al. 2020). Overall, researchers concluded that SARS-CoV-2 RNA was significantly more persistent than infectious SARS-CoV-2, meaning detection of RNA alone does not necessarily prove a risk of infection (Bivins et al. 2020). Limitations of this study included the inability to analyze other environmental factors that may vary in wastewater due to samples originating from only one treatment plant, as well as the use of virus titers that are elevated above the levels that would be expected in the real world (Bivins et al. 2020). Further, a next study reported prolong long stability of SARS-CoV-2 RNA at -20 ${ }^{\circ} \mathrm{C}$ (Hokajärvi et al. 2021), that is, winter ambient temperature in the sub-arctic region.

\section{Significance}

In order to give an idea of the current viral loads, researchers have estimated the SARS-CoV-2 load in municipal wastewater to be 56.6 million to 11.3 billion viral genomes per infected person per day (Hart and Halden 2020). This 


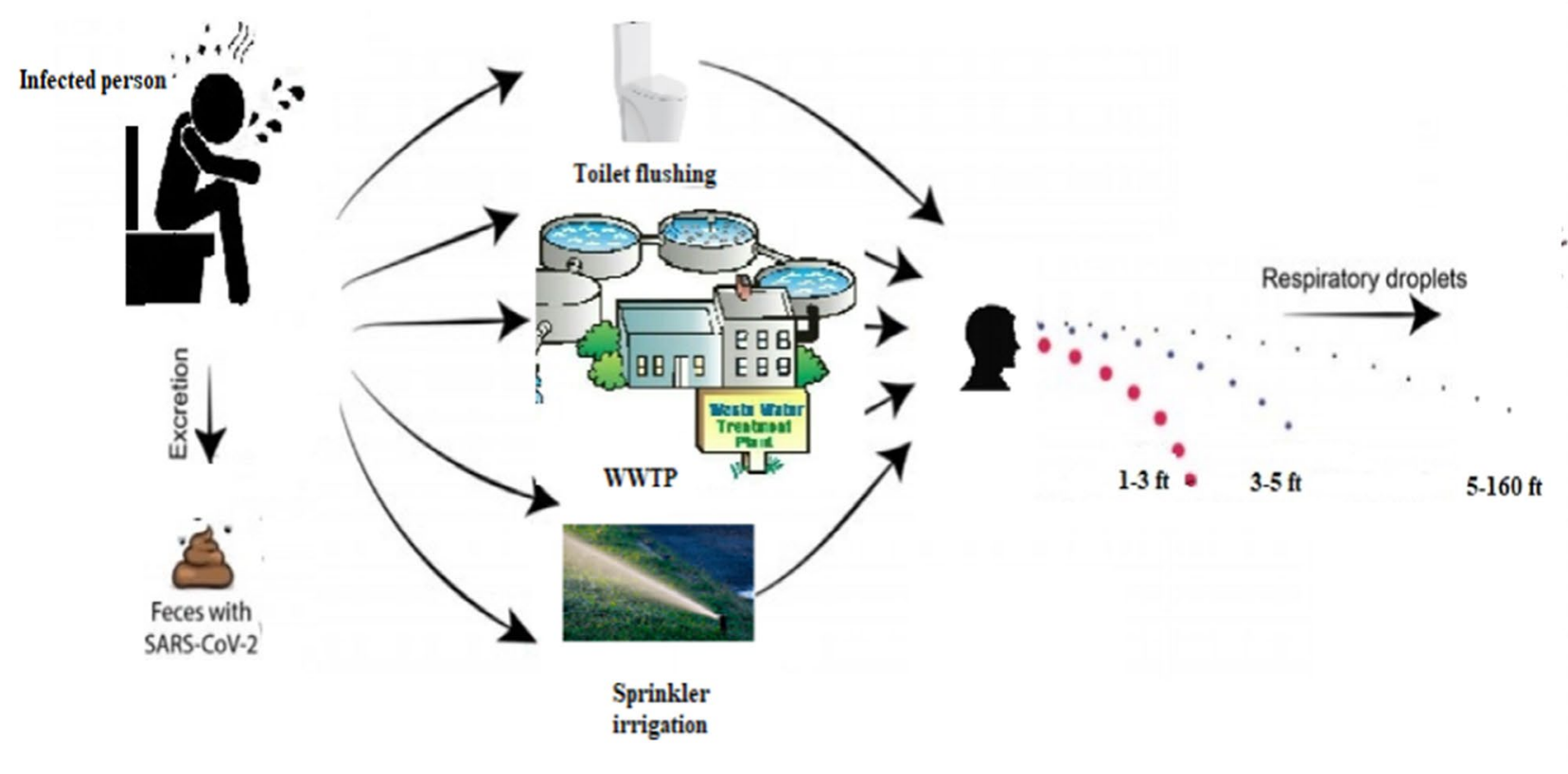

Fig. 2 SARS-CoV-2 transmission through the fecal-oral route

translates into " 0.15 to 141.5 million viral genomes per liter of wastewater generated in North America and Europe" (Hart and Halden 2020, p.3). These estimates are based on the assumption of 100-400 $\mathrm{g}$ feces per day per person at a density of $1.06 \mathrm{~g} / \mathrm{mL}$ and reported the presence of 600,000 to $30,000,000$ viral genomes of SARS-CoV-2 per mL of fecal material (Hart and Halden 2020).

If the fecal-oral hypothesis or possibility of waterborne transmission of SARS-COV-2 is confirmed, new interventions will need to be added to current pandemic control strategies (Heller et al. 2020). This would include methods for providing safe drinking water and proper sanitation, in addition to existing techniques such as hand washing (Heller et al. 2020). However, it should be acknowledged that nearly 2.2 billion people worldwide lack access to safe drinking water, and 4.2 billion lack access to safely managed sanitation (Heller et al. 2020). Therefore, this possible transmission pathway has many implications particularly in areas with poor sanitation (Yeo et al. 2020).

Gwenzi (2021) identifies three possible transmission subpathways for the fecal-oral route including "(1) contaminated drinking water, (2) raw and poorly cooked contaminated aquatic, marine, aquacultural and wastewater-irrigated foods (e.g., salads), and (3) vector-mediated transmission from fecal sources to foods" (p.8) (Figure 2). Drinking water source contamination may occur through leaks into surface or groundwater from on-site sanitation systems, and this contamination risk would be elevated in areas where drinking water and wastewater or on-site sanitation systems are in close proximity or in areas where there are no reliable sources of clean drinking water (Gwenzi 2021). These conditions are common in developing countries, and they also face the challenge of lacking resources for surveilling water systems, as well as properly treating and managing drinking water and wastewater (Gwenzi 2021). Aquatic systems that serve as food sources could be contaminated by the discharge of raw wastewater; however, this possibility requires much more research (Gwenzi 2021). Furthermore, as feces is considered a possible source of COVID-19 transmission, vectors such as flies, rodents, and cockroaches that have contact with or consume infected feces could possibly mechanically transmit the virus (Dehghani and Kassiri 2020). Considering these potential subsequent transmission pathways, it is evident that the possibility of the fecal-oral hypothesis holds significance, especially for developing countries. It should also be noted that wastewater plant workers may be at risk for exposure to SARS-CoV-2 (Tran et al. 2021). Strategies to protect these workers include proper hygiene such as washing hands and avoiding touching the face, wearing appropriate personal protective equipment, and disinfecting surfaces and work clothing (Tran et al. 2021). The following section will provide methods for disinfection of SARSCoV-2 in water.

\section{Methods for disinfection}

In light of the possible waterborne transmission of SARSCoV-2, it is important to identify viable methods for disinfection of the virus in water media. Current methods used for disinfection in water and wastewater treatment plants 
include the use of oxidants such as sodium hypochlorite, peracetic acid, and hydrogen peroxide, as well as exposure to ultraviolet light although it has been seen to be less effective against the virus (Carraturo et al. 2020). Other methods currently used for wastewater sanitation consist of thermal treatment, prolonged holding of wastewater, sedimentation, membrane filtration, and attenuation in subsurface (Buonerba et al. 2021).

It is known that coronaviruses are susceptible to ethanolcontaining antiseptics, as well as disinfectants that contain chlorine or bleach (Yeo et al. 2020). Other "antiseptics and disinfectants, such as halogenated compounds (chlorine, sodium hypochlorite, chloramine, and povidone-iodine), alcohols (ethanol and 2-propanol), aldehydes (formaldehyde and glutaraldehyde), quaternary ammonium compounds, phenolic compounds, and other decontaminating agents," have been proven effective in disinfecting SARS-CoV-2 surrogates such as SARS-CoV-1 and MERS-CoV (Buonerba et al. 2021, p.19). However, chlorine has been identified as the most effective and economical solution for water disinfection concerning viruses as the chemical destroys the viral envelope (Buonerba et al. 2021).

In terms of thermal deactivation, results from the Bivins et al. (2020) study showed viable SARS-CoV-2 concentrations to be reduced by $90 \%$ in 15 and 2 min in 50 and $70{ }^{\circ} \mathrm{C}$ water, respectively. Additionally, Chin et al. (2020) found $30 \mathrm{~min}$ at $56{ }^{\circ} \mathrm{C}$ and $5 \mathrm{~min}$ at $70{ }^{\circ} \mathrm{C}$ were sufficient in deactivating SARS-CoV-2 in culture media. Inactivation by ultraviolet radiation has also been shown to effectively disinfect surfaces and water. One study established lethal doses of ultraviolet $\mathrm{C}$ germicidal radiation for SARS-CoV-2 through in vitro assays (Sabino et al. 2020). Sabino et al. (2020) found lethal doses to inactivate 90 and $99.999 \%$ of SARS-CoV-2 viral particles to be 0.016 and $108.714 \mathrm{~mJ} / \mathrm{cm}^{2}$ in 0.01 and $49.42 \mathrm{~s}$, respectively.

SARS-CoV-2 is sensitive to ultraviolet rays, heat (inactivation temperature of SARS-CoV-2 is about $27^{\circ} \mathrm{C}$ ), and lipid solvents, including ether (75\%), ethanol, chlorinecontaining disinfectant, peroxyacetic acid, and chloroform except for chlorhexidine (Cascella et al. 2021).

\section{Future direction}

Through computational modeling and cost analysis, Hart and Halden (2020) identify water-based epidemiology as a new tool for monitoring SARS-CoV-2 that is quick, inexpensive, and potentially robust. Although water-based epidemiology cannot fully replace clinical testing, it can help notify emergency response personnel of the presence of infected people in certain areas (Hart and Halden 2020). Furthermore, water-based epidemiology studies could be used with spatial tools such as geographical information systems in order to map out potential hotspots (Gwenzi 2021). More research is needed on the survival time of the virus in water and its subsequent infectivity. Additionally, methods for detection of the virus and determining estimates of infective particles may be improved upon. Sanitation and disinfection methods may also be improved, especially in developing countries. Overall, it is important moving forward for researchers to not overlook the possibility of other routes of transmission for SARS-CoV-2 and investigate all possible risks concerning the spread of the virus.

\section{Conclusions}

This paper aimed to summarize the current information surrounding possible fecal-oral or waterborne transmission of SARS-CoV-2 roughly a year after the virus began spreading throughout the world. As researchers worldwide have conducted numerous studies in a short time, it has become clear that SARS-CoV-2 can proliferate in the human gastrointestinal tract. Numerous countries around the world have detected SARS-CoV-2 RNA in their wastewater systems. However, there has been no evidence of individuals contracting COVID-19 from water systems.

Methods identified to disinfect water include chemical disinfection, thermal deactivation, and ultraviolet radiation, among others. It is evident that there is a strong need for more research on the possibility of fecal-oral or waterborne transmission of SARS-CoV-2 (Tiwari et al. 2021; Ahmed et al. 2021). Future directions include more research on survival time and actual infectivity of the virus once it enters water systems. Considering the large impact of the COVID19 pandemic on the entire world, and vulnerable populations such as developing countries and wastewater treatment plant workers, it is crucial to leave no possibility uninvestigated. The COVID-19 pandemic has left unprecedented effects all over the world and has posed a large challenge to our society. As of May 2021, the world is just beginning to see the light at the end of the tunnel of the pandemic, as vaccines for the disease are being distributed. However, our work is nowhere near over as we must stay vigilant and continue to research the disease and prepare for the next pandemic.

Author contribution SS conceptualized and reviewed literature, drafted the initial version, and supervised the overall project. AT, NP, ST, RA, and OT reviewed literature and contributed to the initial version. MM and MHD edited and commented on the initial version of the draft. All authors accepted and approved the final version of the draft.

Funding This research was partially supported by the NIH grant R21AI157434 to Samendra Sherchan. 
Data availability The authors confirm that the data supporting the findings of this study are available within the article.

\section{Declarations}

Ethical approval Not applicable.

Consent to participate Not applicable.

Consent for publication Not applicable.

Competing interests The authors declare no competing interests.

\section{References}

Ahmed W, Angel N, Edson J, Bibby K, Bivins A, O’Brien JW, Choi PM, Kitajima M, Simpson SL, Li J, Tscharke B, Verhagen R, Smith WJM, Zaugg J, Dierens L, Hugenholtz P, Thomas KV, Mueller JF (2020) First confirmed detection of SARS-CoV-2 in untreated wastewater in Australia: a proof of concept for the wastewater surveillance of COVID-19 in the community. Sci Total Environ 728:138764. https://doi.org/10.1016/j.scitotenv. 2020.138764

Ahmed W, Bibby K, D'Aoust PM, Delatolla R, Gerba CP, Haas CN, Hamilton KA, Hewitt J, Julian TR, Kaya D, Monis P, Moulin L, Naughton C, Noble RT, Shrestha A, Tiwari A, Simpson SL, Wurtzer S, Bivins A (2021) Differentiating between the possibility and probability of SARS-CoV-2 transmission associated with wastewater: empirical evidence is needed to substantiate risk. FEMS Microbes 2021;xtab007. https://doi.org/10.1093/femsmc/ xtab007

Al-Tawfiq JA (2020) Asymptomatic coronavirus infection: MERS-CoV and SARS-CoV-2 (COVID-19). Travel Med Infect Dis 35:101608. https://doi.org/10.1016/j.tmaid.2020.101608

Bivins A, Greaves J, Fischer R, Yinda KC, Ahmed W, Kitajima M, Munster VJ, Bibby K (2020) Persistence of SARS-CoV-2 in water and wastewater. Environ Sci Technol Lett 7(12):937-942. https:// doi.org/10.1021/acs.estlett.0c00730

Buonerba A, Corpuz MVA, Ballesteros F, Choo KH, Hasan SW, Korshin GV, Belgiorno V, Barceló D, Naddeo V (2021) Coronavirus in water media: analysis, fate, disinfection and epidemiological applications. J Hazard Mater 125580. https://doi.org/10.1016/j. jhazmat.2021.125580

Cahill N, Morris D (2020) Recreational waters - a potential transmission route for SARS-CoV-2 to humans? Sci Total Environ 740:140122. https://doi.org/10.1016/j.scitotenv.2020.140122

Carducci A, Federigi I, Liu D, Thompson JR, Verani M (2020) Making waves: coronavirus detection, presence and persistence in the water environment: State of the art and knowledge needs for public health. Water Res 179:115907-115907. https://doi.org/10. 1016/j.watres.2020.115907

Carraturo F, Del Giudice C, Morelli M, Cerullo V, Libralato G, Galdiero E, Guida M (2020) Persistence of SARS-CoV-2 in the environment and COVID-19 transmission risk from environmental matrices and surfaces. Environ Pollut 265:115010. https://doi. org/10.1016/j.envpol.2020.115010

Cascella M, Rajnik M, Aleem A, Dulebohn SC, Di Napoli R. Features, evaluation, and treatment of coronavirus (COVID-19). $2021 \mathrm{Apr}$ 20. In: StatPearls [Internet]. Treasure Island (FL): StatPearls Publishing; 2021
Chin AWH, Chu JTS, Perera MRA, Hui KPY, Yen HL, Chan MCW, Peiris M, Poon LLM (2020) Stability of SARS-CoV-2 in different environmental conditions. medRxiv. https://doi.org/10.1101/ 2020.03.15.20036673

Dehghani R, Kassiri H (2020) A brief review on the possible role of houseflies and cockroaches in the mechanical transmission of coronavirus disease 2019 (COVID-19). Archives of Clinical Infectious Diseases, 15(COVID-)

Döhla M, Wilbring G, Schulte B, Kümmerer BM, Diegmann C, Sib E, Richter E, Haag A, Engelhart S, Eis-Hübinger AM, Exner M, Streeck H, Schmithausen RM (2020) SARS-CoV-2 in environmental samples of quarantined households. medRxiv. https://doi. org/10.1101/2020.05.28.20114041

Gazzaz ZJ (2021) Diabetes and COVID-19. Open Life Sciences 16(1):297-302. https://doi.org/10.1515/biol-2021-0034

Goh GK-M, Dunker AK, Foster JA, Uversky VN (2020) Shell disorder analysis predicts greater resilience of the SARS-CoV-2 (COVID19) outside the body and in body fluids. Microbial pathogenesis 144:104177

Gonzalez R, Curtis K, Bivins A, Bibby K, Weir MH, Yetka K, Thompson H, Keeling D, Mitchell J, Gonzalez D (2020) COVID-19 surveillance in Southeastern Virginia using wastewater-based epidemiology. Water Res 186:116296. https://doi.org/10.1016/j. watres.2020.116296

Gwenzi W (2021) Leaving no stone unturned in light of the COVID-19 faecal-oral hypothesis? A water, sanitation and hygiene (WASH) perspective targeting low-income countries. Sci Total Environ 753:141751. https://doi.org/10.1016/j.scitotenv.2020.141751

Hall VJ, Foulkes S, Saei A, Andrews N, Oguti B, Charlett A, Wellington E, Stowe J, Gillson N, Atti A (2021) Effectiveness of BNT162b2 mRNA vaccine against infection and COVID-19 vaccine coverage in healthcare workers in England, multicentre prospective cohort study (the SIREN Study)

Harapan H, Itoh N, Yufika A, Winardi W, Keam S, Te H, Megawati D, Hayati Z, Wagner AL, Mudatsir M (2020) Coronavirus disease 2019 (COVID-19): a literature review. J Infect Public Health 13(5):667-673. https://doi.org/10.1016/j.jiph.2020.03.019

Hart OE, Halden RU (2020) Computational analysis of SARS-CoV-2/ COVID-19 surveillance by wastewater-based epidemiology locally and globally: feasibility, economy, opportunities and challenges. Sci Total Environ 730:138875. https://doi.org/10.1016/j. scitotenv.2020.138875

Hartenian E, Nandakumar D, Lari A, Ly M, Tucker JM, Glaunsinger BA (2020) The molecular virology of coronaviruses. J Biol Chem 295(37):12910-12934. https://doi.org/10.1074/jbc.REV120. 013930

Heller L, Mota CR, Greco DB (2020) COVID-19 faecal-oral transmission: are we asking the right questions? Sci Total Environ 729:138919. https://doi.org/10.1016/j.scitotenv.2020.138919

Hokajärvi AM, Rytkönen A, Tiwari A, Kauppinen A, Oikarinen S, Lehto KM, Kankaanpää A, Gunnar T, Al-Hello H, Blomqvist S, Miettinen IT, Savolainen-Kopra C, Pitkänen T (2021) The detection and stability of the SARS-CoV-2 RNA biomarkers in wastewater influent in Helsinki. Finland Sci Total Environ 770:145274. https://doi.org/10.1016/j.scitotenv.2021.145274

La Rosa G, Bonadonna L, Lucentini L, Kenmoe S, Suffredini E (2020) Coronavirus in water environments: Occurrence, persistence and concentration methods - a scoping review. Water Res 179:115899. https://doi.org/10.1016/j.watres.2020.115899

Medema G, Heijnen L, Elsinga G, Italiaander R, Brouwer A (2020) Presence of SARS-coronavirus-2 RNA in sewage and correlation with reported COVID-19 prevalence in the early stage of the epidemic in The Netherlands. Environ Sci Technol Lett 7(7):511516. https://doi.org/10.1021/acs.estlett.0c00357

Ortiz-Prado E, Simbaña-Rivera K, Gómez-Barreno L, Rubio-Neira M, Guaman LP, Kyriakidis NC, Muslin C, Jaramillo AMG, 
Barba-Ostria C, Cevallos-Robalino D, Sanches-SanMiguel H, Unigarro L, Zalakeviciute R, Gadian N, López-Cortés A (2020) Clinical, molecular, and epidemiological characterization of the SARS-CoV-2 virus and the Coronavirus Disease 2019 (COVID19), a comprehensive literature review. Diagn Microbiol Infect Dis 98(1):115094-115094. https://doi.org/10.1016/j.diagmicrob io. 2020.115094

Paleologos EK, O'Kelly BC, Tang CS, Cornell K, Rodríguez-Chueca J, Abuel-Naga H, Koda E, Farid A, Vaverková MD, Kostarelos K (2020) Post Covid-19 water and waste water management to protect public health and geoenvironment. Environmental Geotechnics 40(XXXX):1-15

Patel M, Chaubey AK, Pittman CU, Mlsna T, Mohan D (2021) Coronavirus (SARS-CoV-2) in the environment: occurrence, persistence, analysis in aquatic systems and possible management. Sci Total Environ 765:142698. https://doi.org/10.1016/j.scitotenv.2020. 142698

Popa A, Genger JW, Nicholson MD, Penz T, Schmid D, Aberle SW et al (2020) Genomic epidemiology of superspreading events in Austria reveals mutational dynamics and transmission properties of SARS-CoV-2. Sci Transl Med 12(573):eabe2555. https://doi. org/10.1126/scitranslmed.abe2555

Race M, Ferraro A, Galdiero E, Guida M, Núñez-Delgado A, Pirozzi F, Siciliano A, Fabbricino M (2020) Current emerging SARS-CoV-2 pandemic: potential direct/indirect negative impacts of virus persistence and related therapeutic drugs on the aquatic compartments. Environ Res 188:109808. https://doi.org/10.1016/j.envres. 2020.109808

Rahmani AM, Mirmahaleh SYH (2021) Coronavirus disease (COVID19) prevention and treatment methods and effective parameters: a systematic literature review. Sustain Cities Soc 64:102568. https:// doi.org/10.1016/j.scs.2020.102568

Randazzo W, Truchado P, Cuevas-Ferrando E, Simón P, Allende A, Sánchez G (2020) SARS-CoV-2 RNA in wastewater anticipated COVID-19 occurrence in a low prevalence area. Water Res 181:115942. https://doi.org/10.1016/j.watres.2020.115942

Romano-Bertrand S, Aho Glele LS, Grandbastien B, Lepelletier D (2020) Preventing SARS-CoV-2 transmission in rehabilitation pools and therapeutic water environments. J Hosp Infect 105(4):625-627. https://doi.org/10.1016/j.jhin.2020.06.003

Sabino CP, Sellera FP, Sales-Medina DF, Machado RRG, Durigon EL, Freitas-Junior LH, Ribeiro MS (2020) UV-C (254 nm) lethal doses for SARS-CoV-2. Photodiagn Photodyn Ther 32:101995101995. https://doi.org/10.1016/j.pdpdt.2020.101995

Sherchan SP, Shahin S, Ward LM, Tandukar S, Aw TG, Schmitz B, Ahmed W, Kitajima M (2020) First detection of SARS-CoV-2 RNA in wastewater in North America: a study in Louisiana, USA. Sci Total Environ 743:140621. https://doi.org/10.1016/j.scitotenv. 2020.140621

Silverman AI, Boehm AB (2020) Systematic review and meta-analysis of the persistence and disinfection of human coronaviruses and their viral surrogates in water and wastewater. Environ Sci Technol Lett 7(8):544-553. https://doi.org/10.1021/acs.estlett.0c00313

Tarighi P, Eftekhari S, Chizari M, Sabernavaei M, Jafari D, Mirzabeigi P (2021) A review of potential suggested drugs for coronavirus disease (COVID-19) treatment. Eur J Pharmacol 895:173890. https://doi.org/10.1016/j.ejphar.2021.173890

Tiwari A, Lipponen A, Hokajärvi A-M, Luomala O, Sarekoski A, Rytkönen A, Österlund P, Al-Hello H, Juutinen A, Miettinen IT, Savolainen-Kopra C, Pitkänen T (2021) Detection and quantification of SARS-CoV-2 RNA in wastewater influent in relation to reported COVID-19 incidence in Finland. https://doi.org/10. $1101 / 2021.10 .05 .21264462$
Tran HN, Le GT, Nguyen DT, Juang R-S, Rinklebe J, Bhatnagar A, Lima EC, Iqbal HMN, Sarmah AK, Chao H-P (2021) SARSCoV-2 coronavirus in water and wastewater: a critical review about presence and concern. Environ Res 193:110265. https:// doi.org/10.1016/j.envres.2020.110265

Van Doremalen N, Bushmaker T, Morris DH, Holbrook MG, Gamble A, Williamson BN, Tamin A, Harcourt JL, Thornburg NJ, Gerber SI (2020) Aerosol and surface stability of SARS-CoV-2 as compared with SARS-CoV-1. N Engl J Med 382(16):1564-1567

Wathore R, Gupta A, Bherwani H, Labhasetwar N (2020) Understanding air and water borne transmission and survival of coronavirus: insights and way forward for SARS-CoV-2. Sci Total Environ 749:141486. https://doi.org/10.1016/j.scitotenv.2020.141486

Westhaus S, Weber F-A, Schiwy S, Linnemann V, Brinkmann M, Widera M, Greve C, Janke A, Hollert H, Wintgens T, Ciesek S (2021) Detection of SARS-CoV-2 in raw and treated wastewater in Germany-suitability for COVID-19 surveillance and potential transmission risks. Sci Total Environ 751:141750. https://doi.org/ 10.1016/j.scitotenv.2020.141750

WHO (2021) Coronavirus disease (COVID-19) pandemic. https:// www.who.int/emergencies/diseases/novel-coronavirus-2019. Accessed 03 May 2021

Wu Y, Guo C, Tang L, Hong Z, Zhou J, Dong X, Yin H, Xiao Q, Tang Y, Qu X, Kuang L, Fang X, Mishra N, Lu J, Shan H, Jiang G, Huang X (2020) Prolonged presence of SARS-CoV-2 viral RNA in faecal samples. The Lancet Gastroenterology \& Hepatology 5(5):434-435. https://doi.org/10.1016/S2468-1253(20)30083-2

Wölfel R, Corman VM, Guggemos W et al (2020). Virological assessment of hospitalized patients with COVID-2019. Nature 581:465-469

Xiao F, Sun J, Xu Y, Li F, Huang X, Li H, Zhao J, Huang J, Zhao J (2020a) Infectious SARS-CoV-2 in feces of patient with severe COVID-19. Emerg Infect Dis 26(8):1920-1922. https://doi.org/ 10.3201/eid2608.200681

Xiao F, Tang M, Zheng X, Liu Y, Li X, Shan H (2020b) Evidence for gastrointestinal infection of SARS-CoV-2. Gastroenterology 158(6):1831-1833.e1833. https://doi.org/10.1053/j.gastro.2020. 02.055

Xing Y, Ni W, Wu Q, Li W, Li G, Tong J, Song X, Xing Q (2020) Prolonged presence of SARS-CoV-2 in feces of pediatric patients during the convalescent phase. medRxiv. https://doi.org/10.1101/ 2020.03.11.20033159

Yazdanpanah F, Asmarz HY, Shadman S (2021) Literature review of COVID-19, pulmonary and extrapulmonary disease. Am J Med Sci. https://doi.org/10.1016/j.amjms.2021.01.023

Yeo C, Kaushal S, Yeo D (2020) Enteric involvement of coronaviruses: is faecal-oral transmission of SARS-CoV-2 possible? The Lancet Gastroenterology \& Hepatology 5(4):335-337. https://doi.org/10. 1016/S2468-1253(20)30048-0

Zhang D, Ling H, Huang X, Li J, Li W, Yi C, Zhang T, Jiang Y, He Y, Deng S, Zhang X, Wang X, Liu Y, Li G, Qu J (2020) Potential spreading risks and disinfection challenges of medical wastewater by the presence of severe acute respiratory syndrome coronavirus 2 (SARS-CoV-2) viral RNA in septic tanks of Fangcang Hospital. Sci Total Environ 741:140445. https://doi.org/10.1016/j.scitotenv. 2020.140445

Publisher's note Springer Nature remains neutral with regard to jurisdictional claims in published maps and institutional affiliations. 